3. Lisova V. V., Romanenko N. M., \& Ovdiy A. K. (2012). Patologoanatomichny zminy za infekciynogo peritonitu cotiv. Scientific papers JNAEU, 1, 3, 338-341 (in Ukrainian).

4. Jashchuk O. V. (2014). Monitiring rospovsjudjennya virusiv sered domashnich cotiv i sobak u m. Dnepropetrovsk. Bulletin of Dnepropetrovsk University. Biology and medicine, 5, 23-27 (in Ukrainian).

5. Pedersen N. C. (2009). A review of feline infectious peritonitis virus infection: 1963-2008. Journal of Feline Medicine and Surgery, 11, 3, 225-258.

Рецензент - д. вет. н. О. П. Мельник, зав. кафедрою анатомії, гістології i патоморфології імені акад. В. Г. Касьяненка НУБіП України.

УДК 612.419:014.3:612.75

doi: 10.36359/scivp.2019-20-2.32

\title{
ХОНДРОГЕННЕ ДИФЕРЕНЦЮЮАННЯ МЕЗЕНХІМАЛЬНИХ СТОВБУРОВИХ КЛІТИН КРОЛЯ, ЗАЛЕЖНО ВІД ТИПУ КУЛЬТУРАЛЬНОЇ СИСТЕМИ
}

\author{
Ю. О. Харкевич ${ }^{1}$, канд. вет. наук, \\ Р. Р. Бокотько , канд. вет. наук, \\ А. Й. Мазуркевич ${ }^{l}$, д-р вет. наук, професор, \\ О. Г. Дерябіна ${ }^{2}$, канд. біол. наук, с. н. с.,

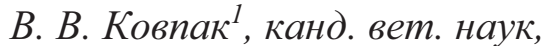 \\ М. О. Малюк', д-р вет. наук, доиент, \\ Л. В. Кладницька ${ }^{l}$ канд. вет. наук, доцент, \\ Ю. В. Дем'янцева ${ }^{1}$, аспірантка \\ ${ }^{1}$ Національний університет біоресурсів і природокористування України, \\ вул. Героїв Оборони, 15, м. Київ, 03041, Україна \\ ${ }^{2} Д У$ «Інститут генетичної та регенеративної медицини НАМН», \\ вул. Вишгородська, 67, м. Київ, 04114, Україна
}

Експериментальне вивчення здатності мезенхімальних стовбурових клітин до хондрогенного диференціювання іп vitro залежно від типу культуральної системи з метою їх подальшого клінічного застосування у ветеринарній медицині для відновлення втрачених функиій пошкодженого суглобового хряща є одним із пріоритетних напрямків наукових досліджень. Репаративна здатність хрящової тканини обмежена, оскільки рівень фізіологічної та репаративної регенерачії хрящової тканини досить низький. 3 огляду на це, триває пошук таких терапевтичних засобів та прийомів, які б дозволяли максимально ефективно відновити порушені структуру і функиію тканин суглобового хряща. Особливе місие у иьому пошуку належсть біотехнології. Мезенхімальні стовбурові клітини кісткового мозку - одна з найбільш вивчених мультипотентних популяцій клітин дорослого організму, яка завдяки здатності до проліфераиії $і$ диферениіювання in vitro, має вагоме значення $в$ клінічній ветеринарній практиці у лікуванні тварин з ураженнями суглобового хряща.

${ }^{6}$ Науковий керівник - д. вет. н., доцент М. О. Малюк 
Встановлено, щзо за апробованого протоколу хондрогенного диференціювання мезенхімальних стовбурових клітин кісткового мозку кроля у моношарі більшість культивованих клітин набуває ниткоподібної форми, щзо призводить до зниження площзі їх адгезії до поверхні культурального пластику $i$, як наслідок, відкріплення у культуральне середовище. Порівняння методів хондрогенного диференціювання мезенхімальних стовбурових клітин кісткового мозку кроля у моношарі та мікромасі показало, щзо ефективнішим є метод диферениіювання клітин у мікромасі, - вже на 21 добу дослідження виявлялись значно більші відкладання клітинами позаклітинного матриксу, порівняно з методом диференціювання у моношарі.

Ключові слова: МЕЗЕНХІМАЛЬНІ СТОВБУРОВІ КЛІТИНИ, ХОНДРОГЕННЕ ДИФЕРЕНЦІЮВАННЯ, КУЛЬТУРАЛЬНА СИСТЕМА, МОНОШАР, МІКРОМАСА.

Дегенеративно-дистрофічні процеси в суглобах тварин характеризуються хронічним прогресуючим порушенням метаболізму в суглобовому хрящі, кісткових структурах епіфізів 3 подальшим втягненням в дегенеративний процес інших елементів суглоба, що супроводжується розвитком деформації суглобів, дисконгруентністю, больовим синдромом, втратою функціональної активності, розвитком вторинного запального процесу в суглобі різної інтенсивності $[4,6]$.

За ушкодження суглобового хряща залишається важливим вирішення питання щодо його репаративних можливостей. Анаеробний характер метаболізму гіалінової хрящової тканини обумовлює низьку інтенсивність процесів обміну речовин у зрілій тканині. Репаративна здатність хрящової тканини обмежена, оскільки рівень фізіологічної та репаративної регенерації хрящової тканини досить низький. В механізмі розвитку деструкції хряща головним патогенетичним фактором $є$ втрата матриксом глікозаміногліканів, які складають основу його міжклітинної речовини [6].

Лікування дегенеративно-дистрофічних захворювань суглобів тварин сьогодні залишається актуальною проблемою, незважаючи на значні успіхи у розкритті численних аспектів їх етіології та патогенезу. Разом з тим, дефекти суглобового хряща практично не відновлюються, найчастіше вони заміщуються волокнистим хрящем, що знижує функціональні властивості новоутвореної тканини. Існуючі нині способи і засоби для лікування захворювань тварин із дегенеративно-дистрофічними змінами в суглобах, нажаль, не дають бажаних результатів.

3 огляду на це, триває пошук таких терапевтичних засобів та прийомів, які б дозволяли максимально відновити порушені структуру і функцію тканин суглобового хряща. Особливе місце у цьому пошуку належить біотехнології $[13,17,3,16]$. Саме з ії розвитком у ветеринарній ортопедичній практиці запроваджується новий вид лікування тварин - клітиннорегенеративна терапія з використанням стовбурових клітин, за допомогою яких відбувається фізіологічна регенерація патологічно змінених тканин протягом життя тварини.

Мезенхімальні стовбурові клітини (МСК) кісткового мозку - одна з найбільш вивчених мультипотентних популяцій клітин дорослого організму, яка завдяки здатності до проліферації і диференціювання in vitro, має вагоме значення в клінічній ветеринарній практиці при лікуванні тварин 3 ураженнями суглобового хряща $[12,2]$. Здатність мезенхімальних стовбурових клітин кісткового мозку диференціюватись у хондрогенному напрямку є одним із основних шляхів спеціалізації цих клітин $[1,18]$, що дає можливість отримувати in vitro із некомітованих клітин-попередниць спеціалізовані клітини суглобового хряща. Разом з тим кількість публікацій з цього важливого і актуального питання обмежені, що стало передумовою для дослідження їх терапевтичного потенціалу при застосуванні та вивчення процесів, які відбуваються в клітинах під час їх спеціалізації.

Для дослідження процесів диференціювання МСК у клітини хрящової тканини та синтезу ними компонентів міжклітинної речовини розроблено різні способи моделювання утворення хрящової тканини in vitro, відмінності яких полягають у зміні складу середовища 
для культивування. Згідно з переважною більшістю протоколів, хондрогенне диференціювання проводять у вигляді тривимірних культур, зокрема культури МСК в мікромасі, яку отримують центрифугуванням попередньо розмножених in vitro МСК у моношарі, або заселенням клітинами декальцинованих кісток чи полімерних матриксів, тощо [1,9]. Культивування МСК у мікромасі дає можливість прослідкувати за синтезом клітинами позаклітинного матриксу. Однак для спостереження за змінами адгезивних властивостей та морфології клітин у динаміці корисним є диференціювання МСК у моношарі.

Застосування тих чи інших протоколів хондрогенного диференціювання МСК, які характеризуються різними підходами щодо здійснення самої процедури та відмінностями у складі та вмісті індукторів у культуральному середовищі, може безпосередньо впливати на морфологічну та функціональну характеристики клітин, що визначатиме їх терапевтичний потенціал [11].

Таким чином, поглиблене експериментальне вивчення здатності МСК до хондрогенного диференціювання in vitro залежно від типу культуральної системи з метою їх подальшого клінічного застосування у ветеринарній медицині для відновлення втрачених функцій пошкодженого суглобового хряща $є$ одним із пріоритетних напрямків наукових досліджень.

Мета дослідження - порівняти ефективність хондрогенного диференціювання мезенхімальних стовбурових клітин кісткового мозку кроля в процесі культивування у моношарі та мікромасі за інтенсивністю утворення клітинами позаклітинного матриксу; встановити морфологічні зміни клітин впродовж диференціювання in vitro в умовах культивування у моношарі.

Матеріали і методи. Отримання кісткового мозку кролів та виділення з нього фракції мононуклеарних клітин 3 високою проліферативною активністю для подальшого культивування здійснювали за розробленими нами методиками.

Культивування клітинної маси для отримання МСК. Клітини розпіпетовували (дезагрегували за допомогою піпетки) та знову центрифугували при $300 \mathrm{~g}$ протягом 5 хв. Відмивання клітин проводили двічі. Осад клітин ресуспензували у відповідній кількості поживного середовища та вносили у чашки Петрі при щільності 50 тис/см². Культивування клітин здійснювали у $\mathrm{CO}_{2}$-інкубаторі при $5 \%$ вмісті $\mathrm{CO}_{2}$ та $37{ }^{0} \mathrm{C}$ у поживному середовищі 3 вмістом 80 \% DMEM та 20 \% FBS з додаванням антибіотику-антимікотику з розрахунку 10 мкл $/ \mathrm{cm}^{3}$ середовища. Субкультивування культури проводили після досягнення клітинами 85-90 \% конфлюентності за допомогою 0,25\%-ого розчину трипсину-Версену. Необхідну кількість мезенхімальних стовбурових клітин отримували впродовж IV пасажів.

Хондрогенне диференціювання MCK in vitro. Для експериментальних досліджень використовували клітини IV пасажу. Диференціювання МСК у моношарі та мікромасі здійснювали впродовж 18-21 діб, після чого культури клітин фарбували відповідними барвниками для виявлення синтезу та депонування клітинами протеогліканів та глікозаміногліканів.

Диференціювання МСК у моношарі проводили за методом, описаним Кучук О.В., в нашій модифікації. 3 цією метою їх інкубували в чашках Петрі ( $\mathrm{S}=9,6 \mathrm{~cm}^{2}$, Sarstedt) у $\mathrm{CO}_{2}$ інкубаторі при $5 \%$ вмісті $\mathrm{CO}_{2}$ та $37{ }^{\circ} \mathrm{C} .3$ метою зменшення площі адгезії клітин до пластику та ущільнення міжклітинних контактів, що є важливою умовою конденсації клітин перед комітуванням у хондрогенному напрямку, клітини IV пасажу культивували до отримання щільності моношару близько $90 \%$ (рис. 1). Для індукції хондрогенезу середовище для культивування замінювали на середовище, призначене для хондрогенного диференціювання. До складу його входить DMEM з високим вмістом глюкози, 50 мкг/мл L-аскорбінової кислоти 2-фосфату, 40 мкг/мл проліну, 100 мкг/мл пірувату натрію, $100 \mathrm{nM}$ дексаметазону, 10 мкг/мл інсуліну ВРХ, 5,5 мкг/мл трансферину, 5 мкг/мл селеніту натрію, 4,7 мкг/мл лінолеїнової кислоти, 0,5 мг/мл сироваткового альбуміну ВРХ, 10 нг/мл трансформуючого фактору росту- 
$\beta 1$. Заміну індукційного середовища проводили кожні 72 год. Контрольну культуру клітин культивували у DMEM з високим вмістом глюкози без додавання індукторів хондрогенезу.

Процес диференціювання МСК у моношарі візуально контролювали за зміною морфології клітин та щільністю самого моношару. Активність продукування клітинами позаклітинного матриксу - глікозаміногліканів - виявляли на 18 добу культивування шляхом фарбування культури клітин 0,1 \% водним розчином барвника сафраніну-О за загальноприйнятою методикою; на 21 добу - шляхом фарбування позаклітинного матриксу у вигляді дрібних вкраплень 1 \%-м альціановим синім за загальноприйнятою методикою. При цьому, протеоглікани при фарбуванні сафраніном-О фарбувалися у оранжево-червоний колір, аглікозаміноглікани при фарбуванні альціановим синім - у блакитний $[1,11]$.

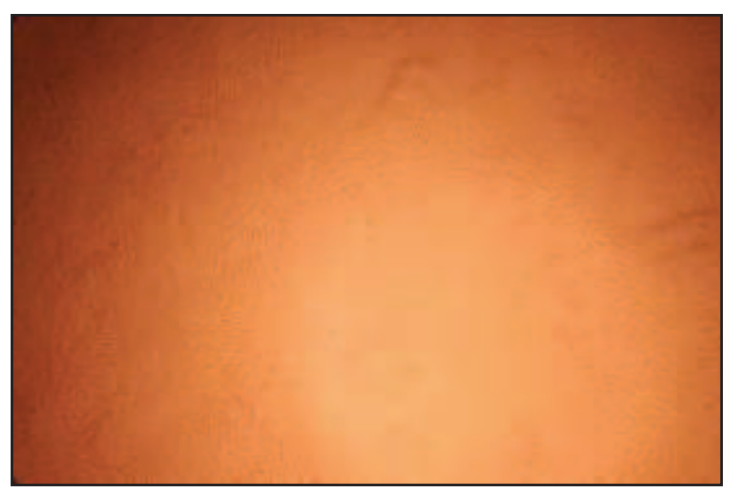

Puc. 1. Загальний вигляд культури МСК перед початком досліду. Нативний препарат. 3б. $\mathrm{x} 140$

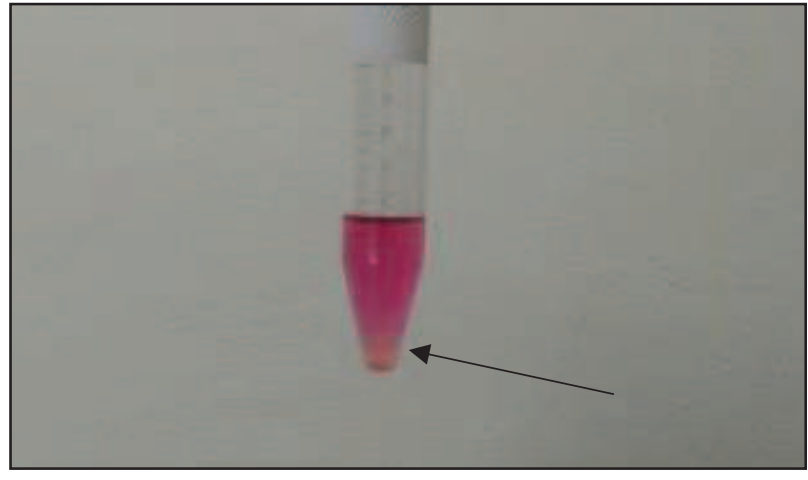

Puc. 2. Загальний вигляд МСК у мікромасі (показано стрілкою)

Диференціювання МСК у мікромасі здійснювали за методом, описаним Кучук О.В., в нашій модифікації у полістиролових стерильних пробірках об'ємом $15 \mathrm{~cm}^{3}$ (рис. 2). Для цього клітини IV пасажу знімали з чашок Петрі, центрифугували протягом 10 хв при 300 g. Після центрифугування при відцентровій силі 300 g відбирали надосадову рідину, а в пробірку додавали середовище для хондрогенного диференціювання такого складу, як і у випадку диференціювання МСК у моношарі. Центрифугування повторювали, після чого пробірки 3 нещільно закритими кришками та осадженими на дно клітинами в кількості 2 млн переносили у $\mathrm{CO}_{2}$-інкубатор для подальшої інкубації 3 вмістом $5 \% \mathrm{CO}_{2}$ та $37{ }^{0} \mathrm{C}$. Заміну індукційного середовища проводили через кожні 72 год.

Контрольну культуру клітин культивували у DMEM з високим вмістом глюкози без додавання індукторів хондрогенезу.

Перебіг процесу диференціювання МСК в осаді клітин візуально контролювали за формуванням мікромаси. Активність продукування клітинами позаклітинного матриксу глікозаміногліканів - виявляли на 21 добу дослідження шляхом фарбування мікромаси клітин $1 \%$-м альціановим синім за загальноприйнятою методикою [11]. Для цього готували мазок клітинної маси на предметних скельцях. Глікозаміноглікани фарбувалися у блакитний колір.

Результати й обговорення. Диферениіювання МСК y моношарі. Активність (ефективність) хондрогенного диференціювання МСК кісткового мозку кроля у моношарі на 3 добу культивування оцінювалась за конфлуентністю моношару у дослідних та контрольних культурах клітин. В культурі клітин дослідних пробірок вона підвищилась на 95 \% і свідчить про інтенсивний перебіг обмінних процесів у клітинах та високу їх проліферативну активність. 3 допомогою світлової мікроскопії встановлено, що в процесі культивування у хондрогенному середовищі більшість клітин дослідних культур змінювала свою морфологію: вони набували більш видовженої форми та займали меншу площу поверхні порівняно 3 клітинами контрольних культур (рис. 3, а). 
На 6-9 доби культивування конфлуентність моношару у контрольних культурах клітин залишилася у межах 95 \%, тоді як у дослідних - зменшилася до 80 \% (рис. 3, б).

Зменшення конфлуентності моношару у дослідних культурах клітин свідчить про втрату ними адгезивних властивостей та зниження проліферативної активності, що $\epsilon$ характерною особливістю МСК, які стали на шлях диференціації. Морфологічно переважна більшість клітин дослідних культур стала ще більш видовженою порівняно 33 добою культивування. Водночас клітини в контрольних культурах лишалися розпластаними на поверхні культурального пластику.

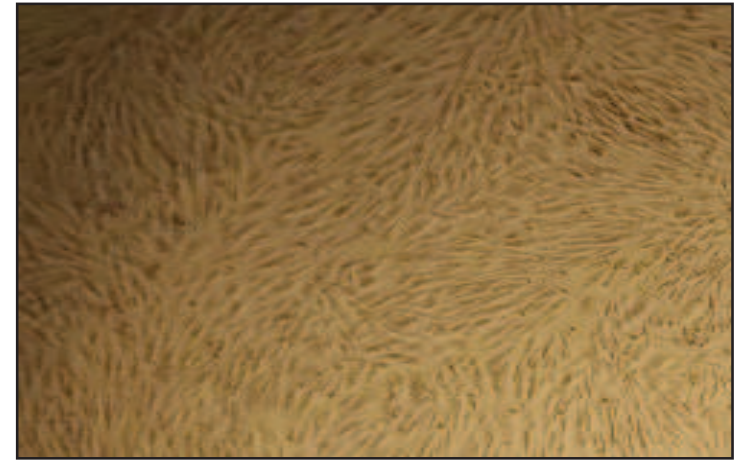

a

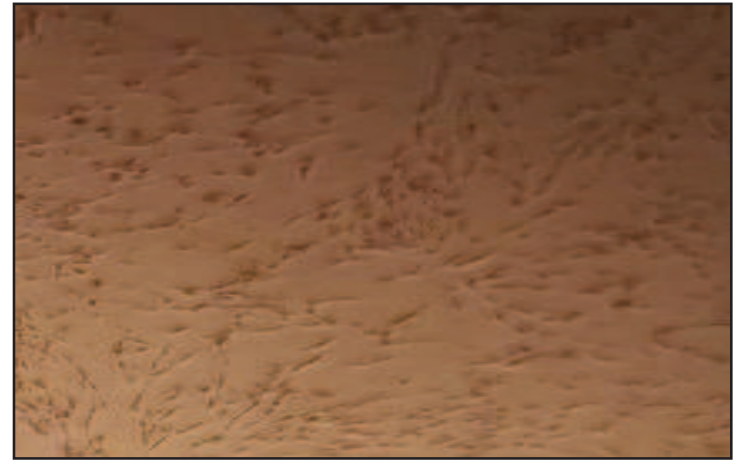

6

Puc. 3. Загальний вигляд культури МСК у досліді із стимулювання хондрогенезу. Нативний препарат: a - 3 доба культивування; б - 9 доба культивування. Зб. х200

В процесі подальшого культивування конфлуентність моношару клітин у дослідних культурах зменшувалася і на 18 добу культивування становила близько 5 \%. Морфологічно більшість клітин втратила фібробластоподібну морфологію: клітини набували ниткоподібної форми та займали малу площу. Разом з тим, у окремих клітин з'являлося більше відростків, вони мали меншу довжину порівняно з попередніми періодами, площа клітин, яка була адгезована до культурального пластика, збільшувалась. Фарбування дослідних культур клітин $0,1 \%$ водним розчином барвника сафраніну - О підтвердило незначне відкладання клітинами протеогліканів, які виявлялися навколо окремих клітин (рис. 4, а).

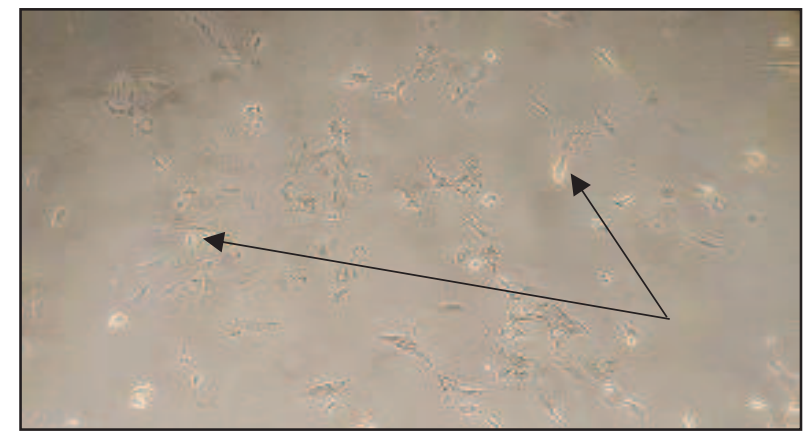

a

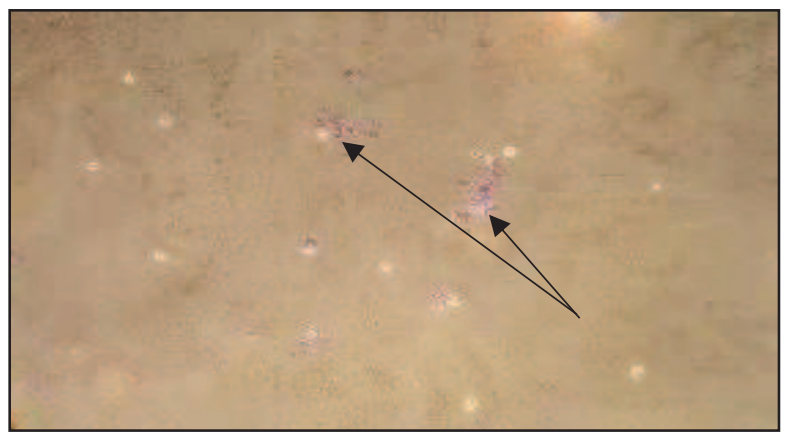

Ћ

Рис. 4. Виявлення глікозаміногліканів в культурі МСК у досліді із стимулювання хондрогенезу (показано стрілками): а - 18 доба дослідження (фарбування сафраніном - O); б - 21 доба дослідження (фарбування альціановим синім). 3б. х200

На 21 добу дослідження у чашках Петрі клітин, адгезованих до дна культурального пластику, не виявилося. Разом з тим, на поверхні культурального пластику мікроскопічно виявляли поодинокі відкладення позаклітинного матриксу у вигляді дрібних вкраплень глікозаміногліканів, що підтверджувалося фарбуванням 1 \%-м альціановим синім (рис. 4, б). 
В контрольних культурах конфлуентність моношару клітин становила близько 100 \%. Більшість клітин зберігала фібробластоподібну морфологію та лишалася розпластаною на поверхні культурального пластику. За рахунок збільшення площі поверхні окремі клітини наче «наростали» на інші.

На 21 добу дослідження, як і в попередній період спостереження, конфлуентність моношару клітин в контрольних культурах становила близько $100 \%$. Фарбування контрольних культур клітин 0,1 \% водним розчином барвника сафраніну-О та 1 \%-м альціановим синім не виявило відкладання клітинами позаклітинного матриксу, характерного для хрящової тканини (рис. 5).

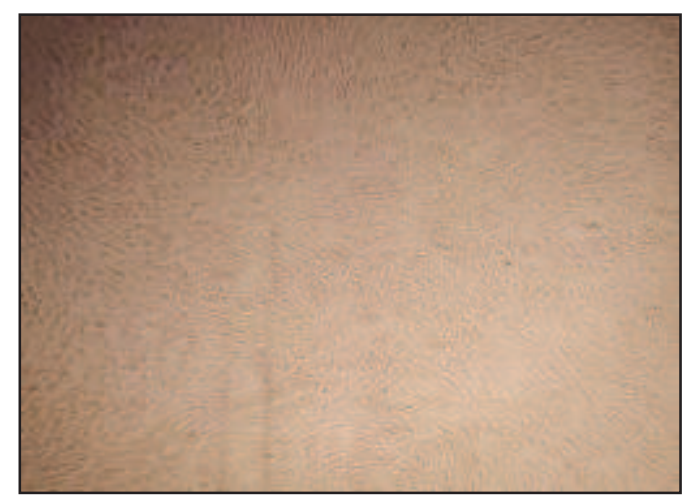

Puc. 5. Контрольна культура МСК на 21 добу дослідження після фарбування альціановим синім: глікозаміногліканів не виявлено. Нативний препарат. 3б. х140

Диференціювання МСК у мікромасі. В процесі культивування МСК кісткового мозку кролів у вигляді осаду у хондрогенному середовищі вже на 6 добу дослідження візуально виявили, що осаджена маса клітин на дні пробірки, на відміну від контролю, набула сферичної форми, що свідчить про компактизацію клітин, що є важливою умовою їх диференціювання у хондрогенному напрямі (рис. 6). Така форма мікромаси клітин зберігалась протягом усього періоду культивування.

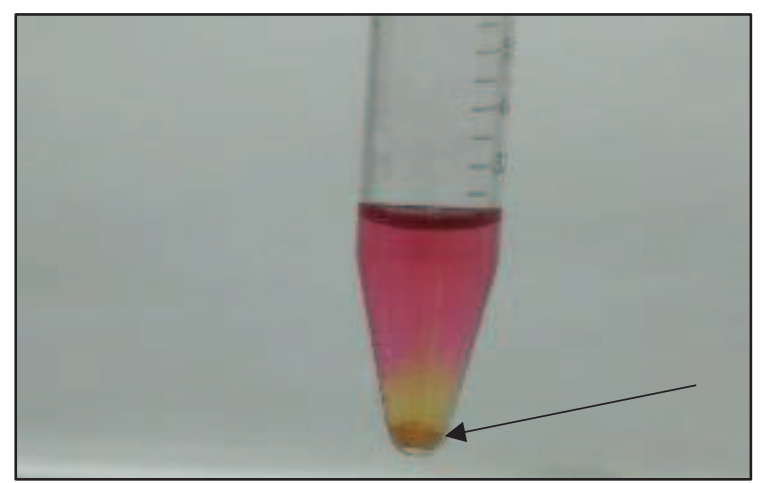

Рис. 6. Дослід із стимулювання хондрогенезу МСК у мікромасі: осаджена маса клітин на дні пробірки набула сферичної форми (показано стрілкою). Нативний препарат

На 21 добу дослідження в мазках із мікромаси МСК, яких культивували у хондрогенному середовищі, при фарбуванні альціановим синім виявили значні відкладання клітинами позаклітинного матриксу, який при взаємодії з барвником набув блакитного забарвлення (рис. 7, а). Така локалізація компонентів позаклітинного матриксу (глікозаміногліканів) є типовою для хондрогенно диференційованих клітин.

В мазку 3 контрольних зразках мікромаси МСК на 21 добу дослідження після фарбування їх альціановим синім відкладень позаклітинного матриксу, характерного для хондрогенно диференційованих клітин, виявлено не було (рис. 7, б). 


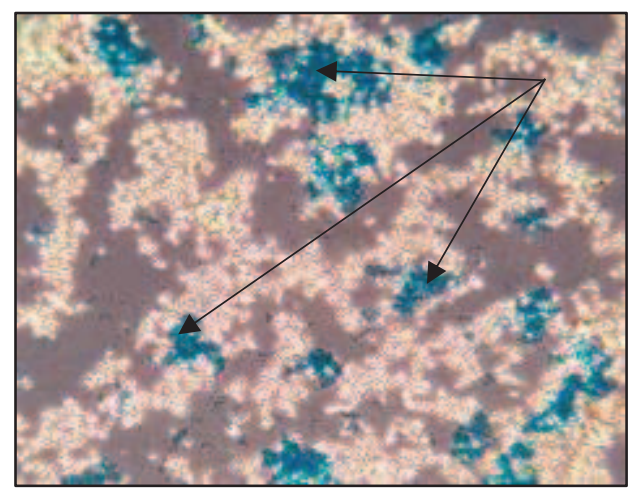

a

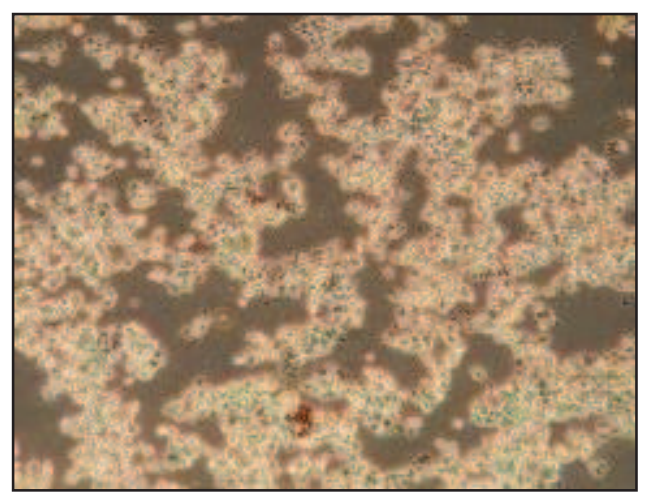

6

Puс. 7. Мазки з мікромаси МСК: а - МСК, культивовані у хондрогенному середовищі: позаклітинний матрикс після фарбування альціановим синім набув блакитного забарвлення (показано стрілками); б - МСК, культивовані у середовищі без індукторів диференціювання: позаклітинного матриксу не виявлено. 3б. Х 140

Таким чином, ефективність хондрогенного диференціювання мезенхімальних стовбурових клітин кісткового мозку кроля залежить від складу використовуваної культуральної системи.

\title{
В И С Н О В К И
}

1. Хондрогенне диференціювання мезенхімальних стовбурових клітин кісткового мозку кроля у моношарі за апробованим нами протоколом показало високу ефективність методу: більшість культивованих клітин набуває ниткоподібної форми, що призводить до зниження площі їх адгезії до поверхні культурального пластику i, як наслідок, сприяє відкріпленню їх у культуральне середовище.

2. Порівняння двох методів хондрогенного диференціювання мезенхімальних стовбурових клітин кісткового мозку кроля показало, що ефективнішим $\epsilon$ метод диференціювання їх у мікромасі: вже на 21 добу дослідження виявлялись значно більші відкладання клітинами позаклітинного матриксу, порівняно 3 дослідом 3 диференціювання МСК у моношарі.

Перспективи досліджень. У подальшому планується дослідити терапевтичну ефективність диференційованих у хондрогенному напрямі мезенхімальних стовбурових клітин за патології суглобового хряща у тварин.

\section{CHONDROGENIC DIFFERENTIATION OF MESENCHAL STEM CELLS OF THE RABBIT DEPENDING ON THE TYPE OF THE CULTURAL SYSTEM}

\author{
Yu. A. Kharkevych ${ }^{1}$, R. R. Bokotko ${ }^{1}$, A. I. Mazurkevych ${ }^{1}$, O. G. Deryabina ${ }^{2}$, V. V. Kovpak', \\ N. A. Malyuk ${ }^{l}$, L. V. Kladnytskal, Yu. V. Demyantseva ${ }^{1}$ \\ ${ }^{1}$ National University of Life and Environmental Sciences of Ukraine \\ 15, Heroyiv Oborony st., Kyiv, 03041, Ukraine \\ ${ }^{2} \mathrm{SO}$ "Institute of Genetic and Regenerative Medicine of the National Academy \\ of Medical Sciences", \\ 67, Vyshgorodska st., Kyiv, 04114, Ukraine
}


Experimental study concerned with the ability of mesenchymal stem cells to chondrogenic differentiation in vitro depending on the type of culture system with a view to their further clinical use in veterinary medicine to restore the lost functions of damaged articular cartilage is one of the priority directions of scientific research. Reparative ability of cartilage tissue is limited, since the level of physiological and reparative regeneration of cartilage tissue is quite low. Given this, the search continues for such therapeutic agents and techniques that most effectively restore the damaged structure and function of the tissues of the articular cartilage. A special place in this search belongs to biotechnology. The bone marrow mesenchymal stem cells are one of the most studied multipotent populations of adult cells, which, due to their ability to proliferate and differentiate in vitro, is of great importance in clinical veterinary practice in treating animals with articular cartilage lesions. It was established that with the used protocol of chondrogenic differentiation of rabbit bone marrow mesenchymal stem cells in the monolayer most of the cultured cells acquire a filamentous form, which leads to a decrease in the area of their adhesion to the surface of the culture plastic and, as a result, detachment into the culture medium. During cultivation the confluence of cell monolayer in experimental cultures decreased and at 18 days of cultivation was about $5 \%$. During cultivation the mesenchymal stem cells in the form of a precipitate in chondrogenic medium, for the 6th day of the study, it was visually discovered that the precipitated mass of cells at the bottom of the test tube became spherical, indicating cell compactification and are important condition for their differentiation in the chondrogenic direction. This form of micromass was maintained throughout the entire period of cultivation. Comparison of chondrogenic differentiation methods of rabbit bone marrow mesenchymal stem cells in monolayer and micromass showed that the method of differentiation of cells in the micromass is more efficient, since as early as 21 days during the study revealed significantly larger depositions of the extracellular matrix by cells compared to monolayer differentiation.

Keywords: MESENCHYMAL STEM CELLS, CHONDROGENIC DIFFERENTIATION, CULTURAL SYSTEM, MONOLAY, MICROMASS.

\title{
ХОНДРОГЕННАЯ ДИФФЕРЕНЦИРОВКА МЕЗЕНХИМАЛЬНЫХ СТВОЛОВЫХ КЛЕТОК КРОЛЯ ЗАВИСИМО ОТ ТИПА КУЛЬТУРАЛЬНОЙ СИСТЕМЫ
}

\author{
Ю. А. Харкевич ${ }^{1}$, Р. Р. Бокотько, А. И. Мазуркевич ${ }^{1}$, О. Г. Дерябина', В. В. Ковпак \\ Н. А. Малюк ${ }^{l}$ Л. В. Кладницкая ${ }^{1}$ Ю. В. Демьянцева ${ }^{l}$ \\ ${ }^{1}$ Национальный университет биоресурсов и природопользования Украины \\ ул. Героев Обороны, 15, г. Киев, 03041, Украина \\ ${ }^{2} Г У$ «Институт генетической и регенеративной медицины НАМН», \\ ул. Вышгородская, 67, г.. Киев, 04114, Украина
}

А Н Н О Т А ЦИ ОЯ

Экспериментальное изучение способности мезенхимальных стволовых клеток к хондрогенной дифференцировке in vitro в зависимости от типа культуральной системы с целью их дальнейшего клинического применения в ветеринарной медицине для восстановления утраченных функций поврежденного суставного хряща является одним из приоритетных направлений научных исследований. Репаративная способность хрящевой ткани ограничена, поскольку уровень физиологической и репаративной регенерации хрящевой ткани достаточно низкий. Учитывая это, продолжается поиск таких терапевтических средств и приемов, позволяющих максимально эффективно восстановить 
нарушенные структуру и функцию тканей суставного хряща. Особое место в этом поиске принадлежит биотехнологии. Мезенхимальные стволовые клетки костного мозга - одна из наиболее изученных мультипотентных популяций клеток взрослого организма, которая, благодаря способности к пролиферации и дифференцировке in vitro, имеет большое значение в клинической ветеринарной практике при лечении животных с поражениями суставного хряща. Установлено, что при апробированном протоколе хондрогенной дифференцировки мезенхимальных стволовых клеток костного мозга кролика в монослое большинство культивируемых клеток приобретает нитевидную форму, что приводит к снижению площади их адгезии к поверхности культурального пластика и, как следствие, открепления в культуральную среду. Сравнение методов хондрогенной дифференцировки мезенхимальных стволовых клеток костного мозга кролика в монослое и микромассе показало, что более эффективным является метод дифференцировки клеток в микромассе, поскольку уже на 21 сутки исследования выявлялись значительно большие откладывания клетками внеклеточного матрикса, по сравнению с дифференцировкой в монослое.

КлючевЫе слова: МЕЗЕНХИМАЛЬНЫЕ СТВОЛОВЫЕ КЛЕТКИ, ХОНДРОГЕННАЯ ДИФФЕРЕНЦИРОВКА, КУЛЬТУРАЛЬНАЯ СИСТЕМА, МОНОСЛОЙ, МИКРОМАССА.

\section{Л I T E P A T У P A}

1. Andrea Heymer. Dissertation zur Erlangung des naturwissenschaftlichen «Chondrogenic Differentiation of Human Mesenchymal Stem Cells and Articular Cartilage Reconstruction». Oberstenfeld, 2008. - P. 116.

2. Effect of intraarticular injection of autologous adipose-derived mesenchymal stem and regenerative cells on clinical signs of chronic osteoarthritis of the elbow joint in dogs / Black L.L., Gaynor J., Adams C. et al. // Vet Ther. - 2008. - Vol. 9. - P. 192-200.

3. Chung C. Engineering Cartilage Tissue / Chung C., Burdick J. A. // Adv Drug Deliv Rev. - 2008. - Vol. 60 (2). - P. 243-262.

4. Деев P. B. Анализ рынка клеточных препаратов для коррекции патологии скелетных тканей / Р.В. Деев // Клеточная трансплантология и тканевая инженерия. - 2006. Вып. 2 (4). - С. 78-83.

5. The relationship between limb function and radiographic osteoarthrosis in dogs with stifle osteoarthrosis / Gordon W.J., Conzemius G., Riedesel E. et al. // Vet Surg. - 2003. - Vol. 32. - P.451454.

6. Hedbom E. Molecular aspects of pathogenesis in osteoarthritis: the role of inflammation / E. Hedbom, H. J. Hauselmann // Cell. Mol. LifeSci. - 2002. - Vol. 59. - P. 45-53.

7. Кучук О. В. Культивирование и направленная остеогенная дифференцировка мультипотентных стромальных клеток костного мозга в культуре микромассы/ О.В. Кучук, Цупиков О. М., Кирик В. М. // Проблемы остеологии. - 2010. - Т.13, No. 4. - С. 36-41.

8. Кучук $O$. B. Скероване хондрогенне диференціювання мультипотентних мезенхімальних стромальних клітин кісткового мозку мишей у моношарі / О.В. Кучук // Біотехнологія. - 2012. - Вип. 5, o. 4. - С. 96-103.

9. Lars-Arne Johansen. Thesis for the degree Master of Pharmacy «Isolation, characterization and chondrogenic differentiation of adult stem cell-derived MUSE-cells». - The Arctic University of Norway, 2016. - P. 63.

10. Вплив алогенних та ксеногенних стовбурових клітин на гомеостаз колінного суглоба кроля при сформованому дефекті хряща / А. Й. Мазуркевич, В. І. Журба, В. В. Ковпак та ін. // Наук.-техн. бюл. Ін-ту біології тварин та Держ. н.-д. контрол. ін-ту ветпрепаратів та корм. Добавок. - 2013. - Вип. 14, № 1/2. - С. 456-460.

11. Mélanie Desancé. Chondrogenic Differentiation of Defined Equine Mesenchymal Stem Cells Derived from Umbilical Cord Blood for Use in Cartilage Repair Therapy / Mélanie Desancé, 
Romain Contentin, Lélia Bertoni et al. // International Journal of Molecular Sciences. - 2018. - Vol. 19 (2). - P. 537

12. Nam H. The effects of staged intra-articular injection of cultured autologous mesenchymal stromal cells on the repair of damaged cartilage: a pilot study in caprine model / Nam H., Karunanithi P., Loo W.C. et al. //Arthritis Res Ther. - 2013. - Vol.15. - R129.

13. Oldershaw R. Cell sources for the regeneration of articular cartilage: the past, the horizon and the future / Oldershaw R. // Int Exp Path. - 2012. - Vol. 93. - P. 389-400.

14. Патент України на корисну модель № 128818, МПК (2018.01) A61D 99/00. Спосіб прижиттєвого отримання кісткового мозку у дрібних тварин/Мазуркевич А.Й., Малюк М.О., Харкевич Ю.О., Дем'янцева Ю.В., Савчук Т.Л. - № u 2018 03592. Заявл. 04.04.2018. Опубл. 10.10.2018. Бюл. № 19.

15. Патент України на корисну модель № 46600, МПК (2009) А61К 35/28. Спосіб отримання фракції мононуклеарних клітин кісткового мозку кролів із високою проліферативною активністю/ Мазуркевич А.Й., Малюк М.О., Ковпак В.В., Харкевич Ю.О., Сушко М.I. - № u 2009 07829. Заявл. 24.07.2009. Опубл. 25.12.2009. Бюл. № 24.

16. Redman S.N. Current strategies for articular cartilage repair/ Redman S.N., Oldfi eld. S.F., Archer C.W. // European Cells and Materials. - 2005. - Vol. 9. - P. 23-32.

17. Roelofs A.J. Cell-based approaches to joint surface repair: a research perspective / Roelofs A.J., Rocke J.P., De B.C. // Osteoarthritis Cartilage. - 2013 - Vol. 21. - P. 892-900.

18. Tondreau T. Isolation of BM mesenchymal stem cells by plastic adhesion or negative selection: phenotype, proliferation kinetics and differentiation potential/ T. Tondreau, L. Lagneaux, M. Dejeneffe et al.// Cytotherapy. - 2004. - Vol. 6, №4. - P. 372-379.

\section{References}

1. Andrea Heymer. Dissertation zur Erlangung des naturwissenschaftlichen «Chondrogenic Differentiation of Human Mesenchymal Stem Cells and Articular Cartilage Reconstruction». Oberstenfeld, 2008. - P. 116.

2. Black L. L. Effect of intraarticular injection of autologous adipose-derived mesenchymal stem and regenerative cells on clinical signs of chronic osteoarthritis of the elbow joint in dogs / Black L.L., Gaynor J., Adams C. et all. // Vet Ther. - 2008. - Vol. 9. - P. 192-200.

3. Chung C. Engineering Cartilage Tissue / Chung C., Burdick JA. //Adv Drug Deliv Rev. 2008. - Vol. 60 (2). - P. 243-262.

4. Deev R.V. Analiz rynka kletochnykh preparatov dl'a korrekcii patologii skeletnykh tkanei/ Deev R.V. // Kletochnaia transplantologia i tkanievaia inzheneria. - 2006. - Vyp. 2 (4). - Str. 7883. (in Russian)

5. Gordon W. J. The relationship between limb function and radiographic osteoarthrosis in dogs with stifle osteoarthrosis / Gordon W.J., Conzemius G., Riedesel E. et al. // Vet Surg. - 2003. Vol. 32. - P.451-454.

6. Hedbom E. Molecular aspects of pathogenesis in osteoarthritis: the role of inflammation / E. Hedbom, H. J. Hauselmann // Cell. Mol. LifeSci. - 2002. - Vol. 59. - P. 45-53.

7. Kuchuk O.V. Kultivirovanie i napravliennaia osteogennaia differencyrovka multipotientnykh stromalnykh klietok kostnogo mozga v kulturie mikromassy / O.V. Kuchuk, O.M. Tsupikov, V.M. Kyryk // Problemy osteologii. - 2010. - T.13, No. 4. - Str. 36-41. (in Russian)

8. Kucuk O.V. Skerovane khondrogenne dyferenciiuvannia multypotentnykh mezenkhimalnykh stromalnykh klityn kistkovogo mozku myshei u monoshari / O. V. Kuchuk // Biotekhnologia - 2012. - Vyp. 5, No. 4. - Str. 96-103. (in Ukrainian)

9. Lars-Arne Johansen. Thesis for the degree Master of Pharmacy «Isolation, characterization and chondrogenic differentiation of adult stem cell-derived MUSE-cells». - The Arctic University of Norway, 2016. - P. 63. 
10. Mazurkevych A. Y. Vplyv alogennykh iksenogennykh stovbyrovykh klityn na gomeostaz kolinnogo sugloba krolia pry sformovanomu defekti khriashcha / A. Y. Mazurkevych, V. I. Zhurba, V. V. Kovpak, Iu. O. Kharkevych, A. G. Milastnaya // Naukovo-tekhnichnyi biuleten Instytutu biologii tvaryn i DNDKI veterynarnykh preperativ i kormovykh dobavok. - 2013. - Vyp. 14, № 1/2. - Str. 456-460 (in Ukrainian)

11. Mélanie Desancé. Chondrogenic Differentiation of Defined Equine Mesenchymal Stem Cells Derived from Umbilical Cord Blood for Use in Cartilage Repair Therapy / Mélanie Desancé, Romain Contentin, Lélia Bertoni et al. // International Journal of Molecular Sciences. - 2018. - Vol. 19 (2). - P. 537

12. Nam H. The effects of staged intra-articular injection of cultured autologous mesenchymal stromal cells on the repair of damaged cartilage: a pilot study in caprine model / Nam H., Karunanithi P., Loo W.C. et al. //Arthritis Res Ther. - 2013. - Vol.15. - R129.

13. Oldershaw R. Cell sources for the regeneration of articular cartilage: the past, the horizon and the future / Oldershaw R. // Int Exp Path. - 2012. - Vol. 93. - P. 389-400.

14. Patent Ukrainy na korysnu model No. 128818, MPK (2018.01) A61D 99/00. Metod pryzhyttievogo otrymannia kistkovogo mozku u dribnykh tvaryn / Mazurkevych A.Y., Malyuk M.O., Kharkevych Iu.O., Demyantseva Y.V., Savchuk T.L. - No. u 2018 03592. Zaiavleno 04/04/2018. Opublikovano 10.10.2018. Bull No. 19. (in Ukrainian).

15. Patent Ukrainy na korysnu model No. 46600, MPK (2009) A61K 35/28. Metod otrymannia frakcii mononuclearnykh klityn z vysokoiu proliferativnoiu actyvnistiu z kistkovogo mozku kroliv/ Mazurkevych A.Y, Malyuk M.O, Kovpak V.V, Kharkevych Iu.O., Sushko M.I. - No. 2009 07829. Zaiavleno 24.07.2009. Opublikovano 25.12.2009. Bull No. 24. (in Ukrainian).

16. Redman S.N. Current strategies for articular cartilage repair/ Redman S.N., Oldfi eld. S.F., Archer C.W. // European Cells and Materials. - 2005. - Vol. 9. - P. 23-32.

17. Roelofs A.J. Cell-based approaches to joint surface repair: a research perspective / Roelofs A.J., Rocke J.P., De B.C. // Osteoarthritis Cartilage. - 2013 - Vol. 21. - P. 892-900.

18. Tondreau T. Isolation of BM mesenchymal stem cells by plastic adhesion or negative selection: phenotype, proliferation kinetics and differentiation potential/ T. Tondreau, L. Lagneaux, M. Dejeneffe et al.// Cytotherapy. - 2004. - Vol. 6, №4. - P. 372-379.

Рецензент - О. П. Мельник, д. вет. н., професор, НУБіП України. 